\title{
Comparison of Two Different Earthquake Sources for the 26 December 2004 Aceh Tsunami Simulation
}

\author{
Nanang T. Puspito \& Indra Gunawan \\ Geophysics Research Group, Institute of Technology Bandung (ITB) \\ Jalan Ganeca 10, Bandung 40132, Indonesia. E-mail: puspito@geoph.itb.ac.id
}

\begin{abstract}
The tsunami wave propagation of the 26 December 2004 Aceh tsunami has been studied by performing a numerical tsunami simulation based on a method that was originally developed by the Tohoku University. The initial model was calculated based on the fault parameters proposed by GFZ Potsdam and Tohoku University. Despite the limitations in the numerical simulation, generally the calculated tsunami heights and arrival times show a relatively good agreement with the observed ones. Based on the simulation it can be estimated that the tsunami wave may reach the west and north coast of northern Sumatra at about 15 to 25 and 20 to 30 minutes after the earthquake, respectively. The maximum calculated tsunami heights in the west and north coast of Aceh were about 11 to 24 and 8 to $15 \mathrm{~m}$, respectively. The calculated arrival times show that the tsunami wave may reach west coast of Thailand and east coast of India and Sri Lanka at about 90 to 100 and 100 to 120 minutes after the earthquake, respectively. The maximum calculated tsunami heights at Phuket of Thailand and Tricomalee of Sri Lanka were about 4 to 5 and 1.5 to $3.5 \mathrm{~m}$, respectively.
\end{abstract}

Keywords: Aceh; tsunami simulation; tsunami wave propagation; tsunami height; arrival time.

\section{Introduction}

The 26 December 2004 Aceh tsunami (often referred as the Indian Ocean tsunami) is considered as the most destructive tsunami ever occurred in the Indonesian region. The tsunami wave swept coastal areas in the Indian Ocean region including Aceh of northern Sumatra, Nicobar and Andaman Islands, Malaysia, Thailand, Myanmar, Bangladesh, India, Sri Lanka, and east coast of Africa. The tsunami caused approximately 250,000 people killed mostly in Aceh, Sri Lanka, India and Thailand.

The 2004 Aceh tsunami - especially their tsunami wave propagation that includes the tsunami heights along the coastal areas and its travel times - is very interesting to be studied. The reported tsunami heights in some places especially in the west coast and north coast of Aceh - were extremely high. Tsuji et al. (2005) reported that the maximum tsunami height in west coast of Aceh was about $34 \mathrm{~m}$ while in north coast of Aceh was about $11 \mathrm{~m}$. Whereas in 
Nicobar and Andaman Islands the maximum tsunami heights were reported about 1 to $7 \mathrm{~m}$ (DOD, 2005).

Seismological studies suggested that the tsunami was generated by a shallow earthquake of magnitude $\mathrm{Mw}=9.0$ (USGS, 2004a) where recent studies (e.g. Stein and Okal, 2005) suggested $\mathrm{Mw}=9.3$. The earthquake occurred in the fore-arc region west of Aceh where the seismic activities are high. Several researchers have studied the source of tsunami, i.e. the seafloor deformation caused by the earthquake (e.g. GFZ Potsdam, 2004; Tohoku University, 2004; Yagi, 2004; Yamanaka, 2004). They proposed several models of seafloor deformation that mainly based on seismological studies. Their proposed models have differences in term of fault parameters. The differences could be studied by analyzing the tsunami wave propagation.

This study attempts to study the tsunami wave propagation of the 2004 Aceh tsunami by performing a numerical tsunami simulation. A method of numerical tsunami simulation that was originally developed by Tohoku University (Imamura et al., 1995; IOC, 1997) was applied in this study. The tsunami simulation was done based on the seafloor deformation models proposed by GFZ Potsdam (2004) and Tohoku University (2004). The calculated tsunami heights and their travel times were discussed and compared with the observed ones.

\section{$2 \quad$ Seismicity and Tsunami in Sumatra}

The Sumatra region where the 2004 Aceh earthquake occurred is characterized by high seismic activities. The region resulted from the convergence of the Indo-Australian and Eurasian plates. The plate motion in the region is relatively simple. Relative to the Eurasian plate, the Indo-Australian plate is moving approximately northward beneath the Eurasian plate. The rate of plate convergence is about $6.0 \mathrm{~cm} /$ year near northern Sumatra and increase to about $6.5 \mathrm{~cm} /$ year near Java (Minster and Jordan, 1978). Based on their seismicity the region is classified to the Western Sunda arc (Puspito and Shimazaki, 1995).

As a result of the plate convergence the Sumatra region is considered as one of the most seismically active regions in Indonesia. Puspito (2002) noted that about $25 \%$ of shallow earthquakes with magnitude $M \geq 6.5$ that occurred in the Indonesian region for a period from 1901 to 2000 occurred in the Sumatra region. Fig. 1 shows seismicity of the Sumatra region. The data was taken from the International Seismological Center (ISC) for a period from 1973 to 1999 with earthquake magnitude $\mathrm{M} \geq 5.0$. There are two seismic zones in the region, i.e. the Sunda subduction zone that is located in the ocean west of Sumatra and the Sumatra fault zone that is located inland. The maximum depth of 
earthquakes beneath Sumatra is about $250 \mathrm{~km}$, while in the east of Sunda strait - a strait that separates Sumatra and Java - the maximum depth is about 650 $\mathrm{km}$. Activities of the two seismic zones have caused many large earthquakes with magnitude $M>7.0$ shown as closed circles in Fig.1. Newcomb and McCann (1987) pointed out that prior to the 2004 Aceh earthquake there were several great earthquakes with magnitude $M>8.0$ occurred in the region since 1800 's.

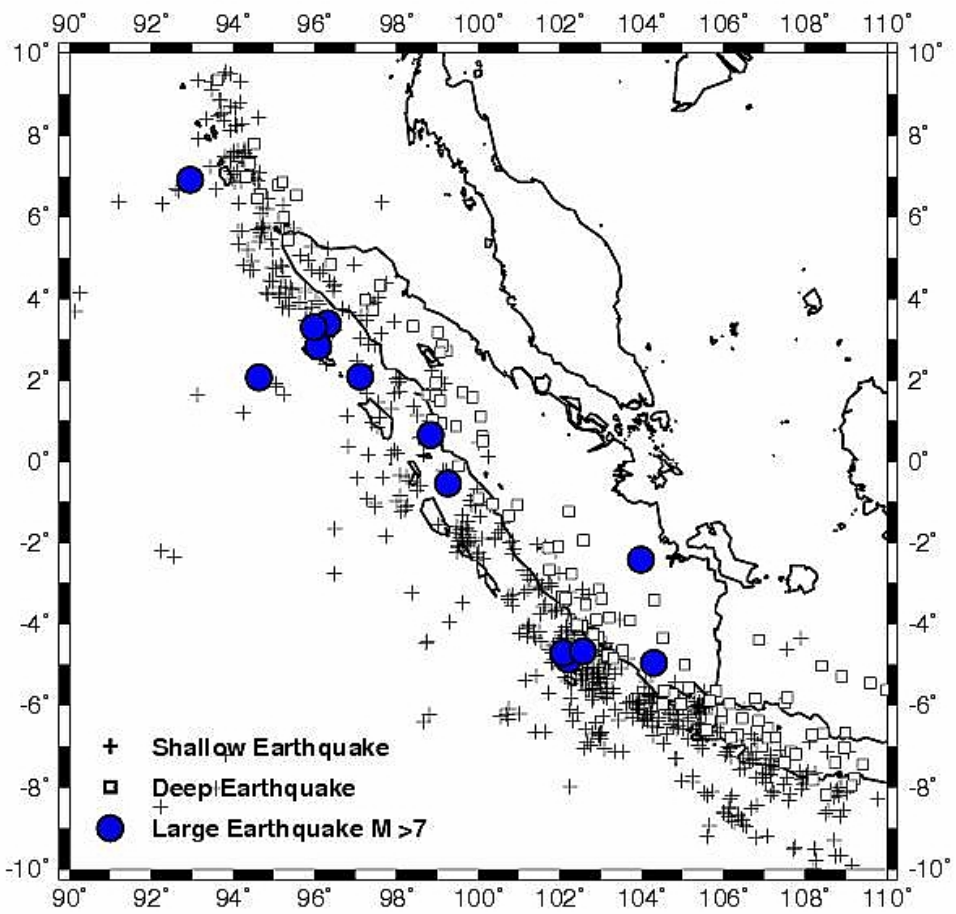

Figure 1 Seismicity of the Sumatra region. The data was taken from the International Seismological Center (ISC) for a period from 1973 to 1999 with magnitude $M \geq 5.0$. Closed circles depict large earthquakes $(M>7.0)$ that occurred in the period from 1801 to 2005 .

Some of the large earthquakes - inter-plate and intra-plate types - that occurred in the recent years have caused thousands of people killed. Among them are the 1994 Liwa earthquake (magnitude $\mathrm{M}=7.2 ; 210$ people killed) and the 1995 Kerinci earthquake (magnitude $\mathrm{M}=7.0 ; 80$ people killed) that occurred inland of Sumatra. The two earthquakes were caused by activities of the Sumatra fault. Whereas the activities of Sunda subduction zone caused the 2000 Bengkulu earthquake (magnitude $\mathrm{M}=7.9 ; 100$ people killed) and the 2005 Nias earthquake (magnitude $\mathrm{M}=8.0 ; 700$ people killed). 


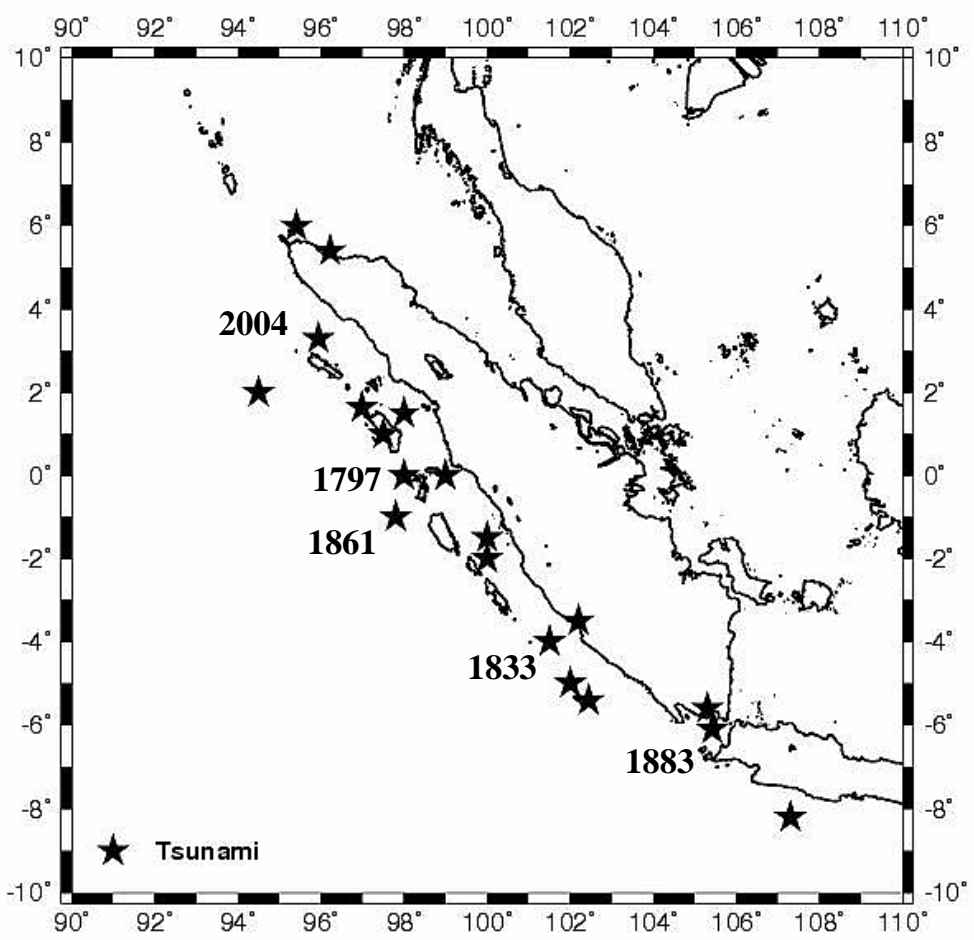

Figure 2 Tsunami Sources in the Sumatra region. The data was compiled from Latief et al. (2000), Gusiakov (2002) and NOAA (2005) for a period from 1770 to 2005. Numbers depict location of sources of the 1797 West Sumatra, 1833 Bengkulu, 1861 West Sumatra, 1883 Krakatau and 2004 Aceh tsunamis.

Occurrence of the 2004 Aceh tsunami has placed the Sumatra region as one of the most tsunami prone regions in Indonesia. The region has been attacked by several large tsunamis including the 1797 West Sumatra, the 1833 Bengkulu, the 1861 West Sumatra and the 1883 Krakatau tsunamis (Latief et al., 2000; Puspito, 2002). The tsunamis have caused thousands of people killed and billions of rupiah losses. Based on the available historical tsunami data (Latief et al., 2000; Gusiakov, 2002; NOAA, 2005) there were 20 tsunamis occurred in the region for a period from 1770 to 2005 . Among them 19 tsunamis were caused by earthquakes and one tsunami caused by the 1883 Krakatau eruption. Fig. 2 shows distribution of the tsunami sources in the Sumatra region. It can be seen from Fig. 2 that most the tsunamigenic earthquakes occurred along the fore-arc region, although it should be noted that further study on the precise location of tsunami sources is still needed. It could also be suggested that the tsunamigenic earthquakes in the Sumatra region were caused by activities of the Sunda subduction zone. 


\section{The 2004 Aceh Earthquake}

The 2004 Aceh earthquake is located near Simeuleu Island in the fore-arc region at latitude $3.30^{\circ}$ North and longitude $95.95^{\circ}$ East occurred at 00:58:53 UTC or 07:58:53 AM local time. The focal depth is reported about $20 \mathrm{~km}$ and the moment magnitude $\mathrm{Mw}=9.0$ (USGS, 2004a) where Stein and Okal (2005) suggested $\mathrm{Mw}=9.3$. The earthquake is considered as the second largest earthquake in the last 45 years after the 1960 Chile earthquake $(\mathrm{Mw}=9.5)$ that generated a large tsunami in the Pacific region.

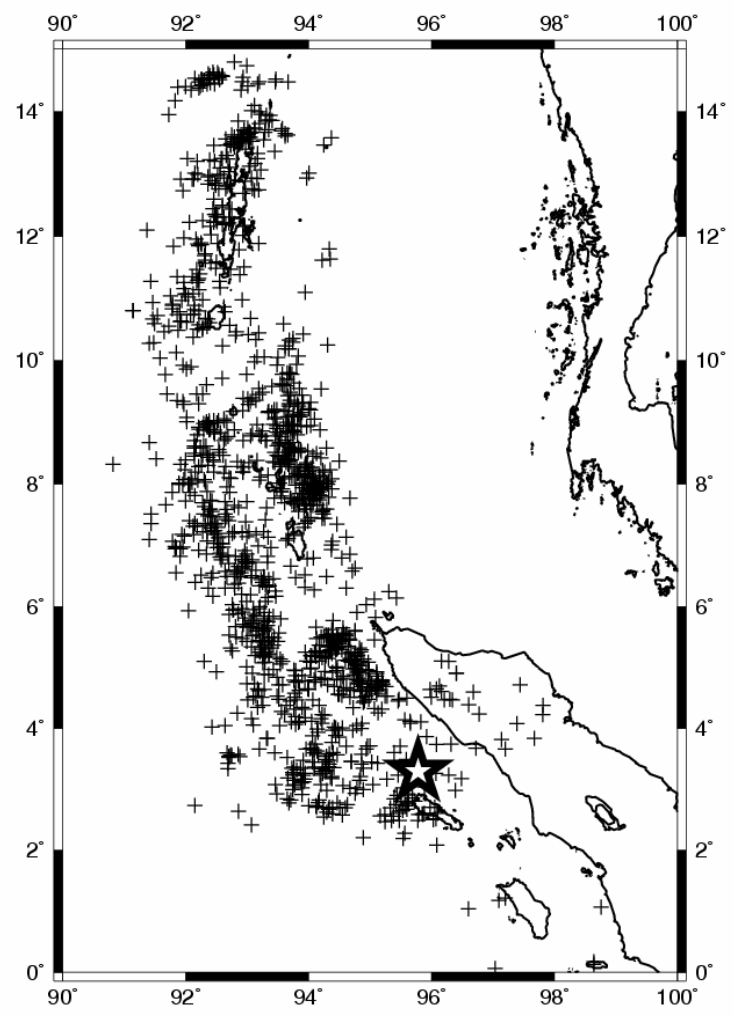

Figure 3 Aftershocks Distribution. The data was taken from USGS (2004b) for a period from 26 to 31 December 2004. The star depicts location of the 2004 Aceh earthquake.

The 2004 Aceh earthquake has been followed by hundreds of aftershocks that distributed almost northward from Simeuleu Island at latitude of about $3^{0}$ North to Andaman Islands at latitude of about $14^{0}$ North. Fig. 3 shows aftershocks 
distribution that occurred from 26 to 31 December 2004 where the data was taken from USGS (2004b). The 2004 Aceh earthquake is shown as a big star in Fig. 3. Based on the CMT (centroid moment tensor) solution of Harvard University the earthquake focal mechanism was interpreted as a reverse type with strike $=329^{\circ}$, dip $=8^{0}$, and rake $=110^{\circ}$ (Harvard University, 2004). The CMT solution confirmed that the 2004 Aceh earthquake is a mega thrust earthquake with low angle of dip. Fig. 4 shows some focal mechanisms of the aftershocks taken from the CMT solutions of Harvard University.

Table 1 The Proposed Fault Parameters.

\begin{tabular}{|c|c|c|c|c|}
\hline $\begin{array}{c}\text { Fault } \\
\text { parameters }\end{array}$ & Yagi (2004) & $\begin{array}{c}\text { Yamanaka } \\
(2004)\end{array}$ & $\begin{array}{c}\text { Tohoku Univ. } \\
(2004)\end{array}$ & $\begin{array}{c}\text { GFZ Potsdam } \\
(2004) \\
\end{array}$ \\
\hline \multicolumn{5}{|l|}{ Segment-1: } \\
\hline Strike/Dip/Rake & $329^{0} / 10^{0} / 110^{0}$ & $340^{0} / 8^{0} / 112^{0}$ & $\begin{array}{c}329^{0} / 15^{0} / \\
110^{0}\end{array}$ & $295^{0} / 12^{0} / 110^{0}$ \\
\hline Length/Width & $600 \mathrm{~km} / 150 \mathrm{~km}$ & $\begin{array}{c}140 \mathrm{~km} / 200 \\
\mathrm{~km}\end{array}$ & $\begin{array}{c}330 \mathrm{~km} / 150 \\
\mathrm{~km}\end{array}$ & $209 \mathrm{~km} / 150 \mathrm{~km}$ \\
\hline Maximum Slip & 11 meters & 8.9 meters & 11 meters & 15 meters \\
\hline \multicolumn{5}{|l|}{ Segment-2: } \\
\hline Strike/Dip/Rake & & $340^{0} / 8^{0} / 112^{0}$ & $\begin{array}{c}340^{0} / 15^{0} / \\
110^{0} \\
\end{array}$ & $330^{\circ} / 12^{0} / 110^{0}$ \\
\hline Length/Width & & $\begin{array}{l}340 \mathrm{~km} / \\
200 \mathrm{~km}\end{array}$ & $\begin{array}{c}570 \mathrm{~km} / 150 \\
\mathrm{~km}\end{array}$ & $179 \mathrm{~km} / 150 \mathrm{~km}$ \\
\hline Maximum Slip & & 8.9 meters & 11 meters & 15 meters \\
\hline \multicolumn{5}{|l|}{ Segment-3: } \\
\hline Strike/Dip/Rake & & $340^{0} / 8^{0} / 112^{0}$ & $5^{0} / 15^{0} / 110^{0}$ & $350^{0} / 12^{0} / 110^{0}$ \\
\hline Length/Width & & $\begin{array}{l}420 \mathrm{~km} / \\
200 \mathrm{~km}\end{array}$ & $\begin{array}{c}300 \mathrm{~km} / \\
\mathrm{km}\end{array}$ & $259 \mathrm{~km} / 150 \mathrm{~km}$ \\
\hline Maximum Slip & & 8.9 meters & 11 meters & 15 meters \\
\hline \multicolumn{5}{|l|}{ Segment-4: } \\
\hline Strike/Dip/Rake & & & & $331^{0} / 12^{0} / 110^{0}$ \\
\hline Length/Width & & & & $229 \mathrm{~km} / 150 \mathrm{~km}$ \\
\hline Maximum Slip & & & & 15 meters \\
\hline \multicolumn{5}{|l|}{ Segment-5: } \\
\hline Strike/Dip/Rake & & & & $349^{0} / 12^{0} / 110^{0}$ \\
\hline Length/Width & & & & $181 \mathrm{~km} / 150 \mathrm{~km}$ \\
\hline Maximum Slip & & & & 15 meters \\
\hline \multicolumn{5}{|l|}{ Segment-6: } \\
\hline Strike/Dip/Rake & & & & $13^{0} / 12^{0} / 110^{0}$ \\
\hline Length/Width & & & & $307 \mathrm{~km} / 150 \mathrm{~km}$ \\
\hline Maximum Slip & & & & 15 meters \\
\hline
\end{tabular}




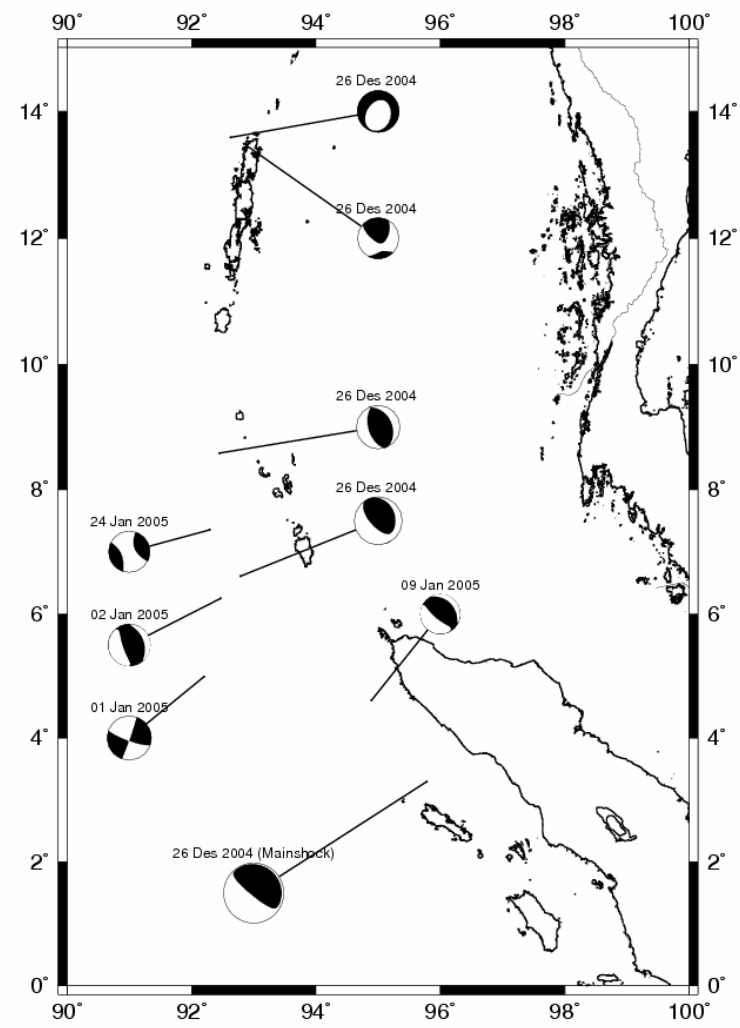

Figure 4 The CMT Solutions. The centroid moment tensor (CMT) solutions were taken from were taken from Harvard University (2004). Only aftershocks of shallow earthquakes with magnitude $M>6.5$ were selected.

Several researchers have studied the sea floor deformation caused by the earthquake in term of earthquake rupture area (e.g. GFZ Potsdam, 2004; Tohoku University, 2004; Yagi, 2004; Yamanaka, 2004). They proposed several models that have differences in term of fault parameters. Yagi (2004) proposed that the rupture area is one segment with size of about $600 \mathrm{~km} \times 150$ $\mathrm{km}$ and the maximum slip is about $11 \mathrm{~m}$. Yamanaka (2004) proposed a rupture area that consists of 3 segments. The size of the rupture area in total is about $910 \mathrm{~km} \times 200 \mathrm{~km}$ while the maximum slip is about $8.9 \mathrm{~m}$. Tohoku University (2004) proposed that the size of the rupture area in total is about $1200 \mathrm{~km} \times 150$ $\mathrm{km}$. The rupture area consists of 3 segments with maximum slip of about $11 \mathrm{~m}$. GFZ Potsdam (2004) proposed a rupture area that consists of 6 segments. The size of the rupture area in total is about $1360 \mathrm{~km} \times 150 \mathrm{~km}$ and the maximum slip is about $15 \mathrm{~m}$. Table 1 summarizes the proposed fault parameters. Recent 
studies (Ammon et al., 2005; Bilham, 2005; Ishii et al., 2005; Lay et al., 2005; Stein and Okal, 2005) estimated that the total length of rupture area was about 1200 to $1300 \mathrm{~km}$. Fig. 3 also indicates that the aftershocks were distributed almost northward with total length of about $1200-1300 \mathrm{~km}$. Judging from the distribution of aftershocks and the recent studies it could be suggested that the models proposed by GFZ Potsdam (2004) and Tohoku University (2004) are more reliable than the ones proposed by Yagi (2004) and Yamanaka (2004).

\section{The Tsunami Simulation}

In order to study the nature of tsunami wave propagation - tsunami heights and its travel times - a numerical tsunami simulation was performed by utilizing a method that was originally developed by Tohoku University, Japan (Imamura et al., 1995; IOC, 1997). The tsunami simulation basically is aimed to calculate the tsunami heights and its travel times in space and time. The tsunami is assumed as a shallow water wave where the wavelength is much larger than the depth of sea floor. Some basic equations that applied in the method as follows

Continuity equation:

$$
\frac{\partial \eta}{\partial t}+\frac{\partial M}{\partial x}+\frac{\partial N}{\partial y}=0
$$

Governing equation:

$$
\begin{aligned}
& \frac{\partial M}{\partial t}+\frac{\partial}{\partial x}\left(\frac{M^{2}}{D}\right)+\frac{\partial}{\partial y}\left(\frac{M N}{D}\right)+g D \frac{\partial \eta}{\partial x}+\frac{g n^{2}}{D^{7 / 3}} M \sqrt{M^{2}+N^{2}}=0 \\
& \frac{\partial N}{\partial t}+\frac{\partial}{\partial x}\left(\frac{M N}{D}\right)+\frac{\partial}{\partial y}\left(\frac{N^{2}}{D}\right)+g D \frac{\partial \eta}{\partial y}+\frac{g n^{2}}{D^{7 / 3}} N \sqrt{M^{2}+N^{2}}=0
\end{aligned}
$$

Where $x$ and $y$ are space coordinates in horizontal direction, $t$ is time, $M$ and $N$ are discharge in $\mathrm{x}$ - and y-direction respectively, $\eta$ is water elevation, $D(=h+$ $\eta$ ) is total depth where $h$ is water depth, $n$ is Manning's roughness coefficient and $\mathrm{g}$ is gravitational acceleration. The $5^{\text {th }}$ component in equations (2) and (3) represent the bottom friction where the Manning's roughness coefficient $n$ is related with the bottom friction coefficient f by $n=\sqrt{\frac{f D^{1 / 3}}{2 g}}$.

It is noted that the bottom friction $f$ becomes rather larger as the total depth is shallower, as long as the Manning's roughness $n$ is almost constant (Imamura, 1996). 
In this study the equations (2) and (3) were solved linearly by neglecting the $2^{\text {nd }}$, $3^{\text {rd }}$, and the $5^{\text {th }}$ components so that the equations (2) and (3) become

$$
\begin{aligned}
& \frac{\partial M}{\partial t}+g D \frac{\partial \eta}{\partial x}=0 \\
& \frac{\partial N}{\partial t}+g D \frac{\partial \eta}{\partial y}=0
\end{aligned}
$$

In this study the equations (1), (4) and (5) were solved numerically by applying a finite different method of Leap Frog Staggered (Imamura et al., 1995; IOC, 1997). The leap-frog scheme used in this study is a central difference scheme with the truncation error of the second order. Fig. 5 shows arrangement of points for computation in the leap-frog method. Suffixes (i, j, k) are used to express the spatial position $(\mathrm{x}, \mathrm{y})$ and the time $\mathrm{t}$.
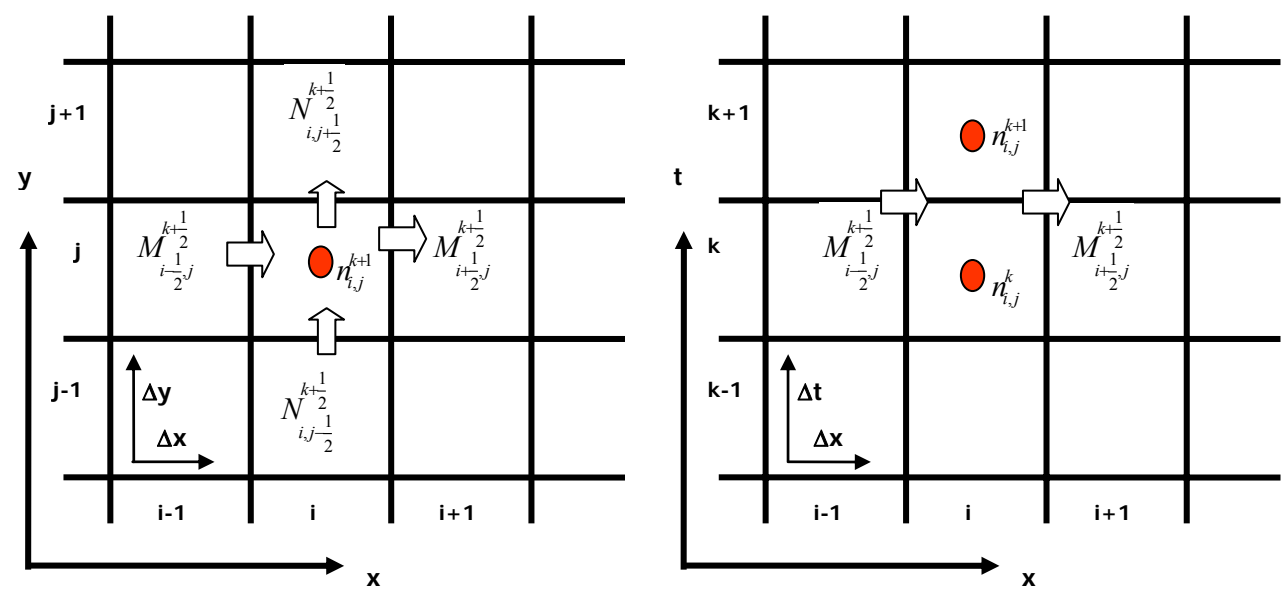

Figure 5 Arrangement of Points for Computation in the Leap-Frog Method. Suffixes $\mathrm{i}, \mathrm{j}$, and $\mathrm{k}$ are used to express the spatial position $\mathrm{x}, \mathrm{y}$ and the time $\mathrm{t}$, respectively.

First, the equation of continuity is approximated by a difference equation. With the central difference scheme, three terms in equation (1) are given by

$$
\begin{aligned}
& \frac{\partial \eta}{\partial t}=\frac{1}{\Delta t}\left[\eta_{i, j}{ }^{k+1}-\eta_{i, j}{ }^{k}\right] \\
& \frac{\partial M}{\partial x}=\frac{1}{\Delta x}\left|M_{i+\frac{1}{2}, j}^{k+\frac{1}{2}}-M_{i-\frac{1}{2}, j}^{k+\frac{1}{2}}\right|
\end{aligned}
$$




$$
\frac{\partial N}{\partial y}=\frac{1}{\Delta y}\left[N_{i, j+\frac{1}{2}}^{k+\frac{1}{2}}-N_{i, j-\frac{1}{2}}^{k+\frac{1}{2}}\right]
$$

On assuming that values at $\mathrm{k}$ and $\mathrm{k}+1 / 2$ time steps are known, the only unknown $\eta(\mathrm{i}, \mathrm{j}, \mathrm{k}+1)$ is solved by

$$
\eta_{i, j}^{k+1}=\eta_{i, j}^{k}-\frac{\Delta t}{\Delta x}\left|M_{i+\frac{1}{2}, j}^{k+\frac{1}{2}}-M_{i-\frac{1}{2}, j}^{k+\frac{1}{2}}\right|-\frac{\Delta t}{\Delta y}\left|N_{i, j+\frac{1}{2}}^{k+\frac{1}{2}}-N_{i, j-\frac{1}{2}}^{k+\frac{1}{2}}\right|
$$

Second, the equation of motion is approximated. The linear equation of motion in the x-direction is given by equation (4). A central difference at the point $(\mathrm{i}+1 / 2, \mathrm{j}, \mathrm{k})$ yields the following equation for an unknown $\mathrm{M}(\mathrm{i}+1 / 2, \mathrm{j}, \mathrm{k}-1 / 2)$

$$
M_{i+\frac{1}{2}, j}^{k+\frac{1}{2}}=M_{i+\frac{1}{2}, j}^{k-\frac{1}{2}}-g D_{i+\frac{1}{2}, j}^{k} \frac{\Delta t}{\Delta x}\left[\eta_{i+1, j}^{k}-\eta_{i, j}^{k}\right]
$$

where the total water depth $D(i+1 / 2, j, k)$ is expressed by

$$
D_{i+\frac{1}{2}, j}^{k}=h_{i+\frac{1}{2}, j}-\eta_{i+\frac{1}{2}, j}^{k}=h_{i+\frac{1}{2}, j}+\frac{1}{2}\left[\eta_{i+1, j}^{k}+\eta_{i, j}^{k}\right]
$$

The similar manipulation yields the following difference equation for the linear equation of motion in the $y$-direction given in equation (5)

$$
\begin{aligned}
& N_{i, j+\frac{1}{2}}^{k+\frac{1}{2}}=N_{i, j+\frac{1}{2}}^{k-\frac{1}{2}}-g D_{i, j-\frac{1}{2}}^{k} \frac{\Delta t}{\Delta y}\left[\eta_{i, j+1}^{k}+\eta_{i, j}^{k}\right] \\
& D_{i, j+\frac{1}{2}}^{k}=h_{i, j+\frac{1}{2}}+\eta_{i, j+\frac{1}{2}}^{k}=h_{i, j+\frac{1}{2}} \frac{1}{2}\left[\eta_{i, j+1}^{k}+\eta_{i, j}^{k}\right]
\end{aligned}
$$

It is now possible to solve equations (9), (10) and (12) simultaneously and obtain the solution of linear long waves. A comment is necessary to explain a difference between the origin equation of linear long waves and equations (10) and (12). The original equation of linear long waves uses $h$ (still water depth), but equations (10) and (12) use $D$ (total water depth). If $h$ is sufficiently larger than $\eta$, a linear computation with equations (10) and (12) can yields reliable result. It should be kept in mind that this linear computation may become unstable if $h$ is smaller than $\eta$. In order to ensure the stability of the computation the temporal grid $\Delta t$ and spatial grid $\Delta x$ should satisfy $\Delta x / \Delta t \geq \mathrm{C}$, where $\mathrm{C}$ is the propagation velocity that is assumed constant. 


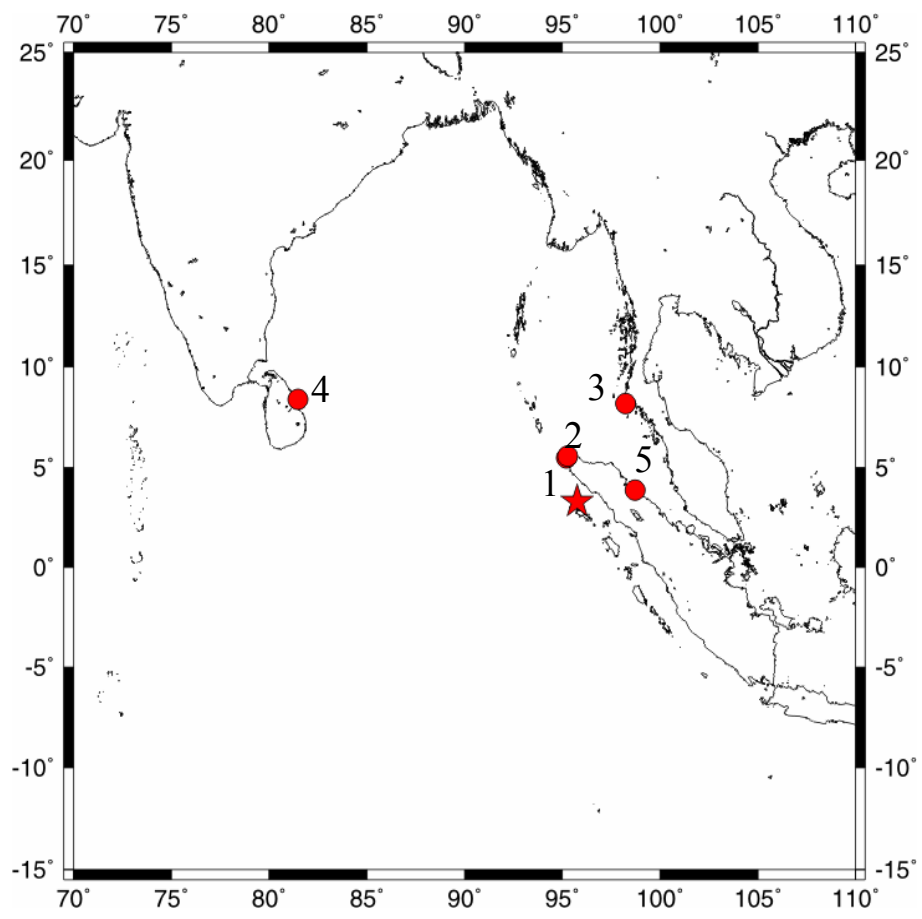

Figure 6 The Study Area. The study area covers most of the northern part of the Indian Ocean region and has a size of $400 \times 400$. The star depicts location of the 2004 Aceh earthquake. The closed circles depict location, for which time series of the tsunami elevation were calculated and presented in Figs. 11, 12 and 13. Numbers 1, 2, 3, 4 and 5 denote the location of Lhoknga, Banda Aceh, Phuket of Thailand, Tricomalee of Sri Lanka and Belawan, respectively.

The computation was done by assuming that no wind waves and tides are included. The still water level is given by tides and is assumed constant during the computation. This means that no motion is assumed up to time k-1/2. Therefore, the initial condition in sea is set as

$$
\eta_{i, j}^{k-1}=0, \quad M_{i+\frac{1}{2}, j}^{k-\frac{1}{2}}=0, \quad N_{i, j+\frac{1}{2}}^{k-\frac{1}{2}}=0
$$

For tsunami simulation in a deep sea including a tsunami source, there are two kinds of initial condition with and without dynamic effects of fault motion (rupture velocity and rising time). In such dynamic effects can be negligible for tsunami initial propagation, the final vertical deformation of the sea bottom caused by the fault is given as the initial water surface. The equation (1) is modified as 


$$
\frac{\partial \eta}{\partial t}+\frac{\partial M}{\partial x}+\frac{\partial N}{\partial y}=\frac{\partial \zeta}{\partial t}
$$

where $\zeta$ is the vertical deformation of sea bottom. The boundary condition on land is the perfect reflection. The velocity component (discharge flux component) normal to the land boundary is made equal to zero so that

$$
\frac{\partial M}{\partial x}=0 ; \frac{\partial N}{\partial x}=0
$$

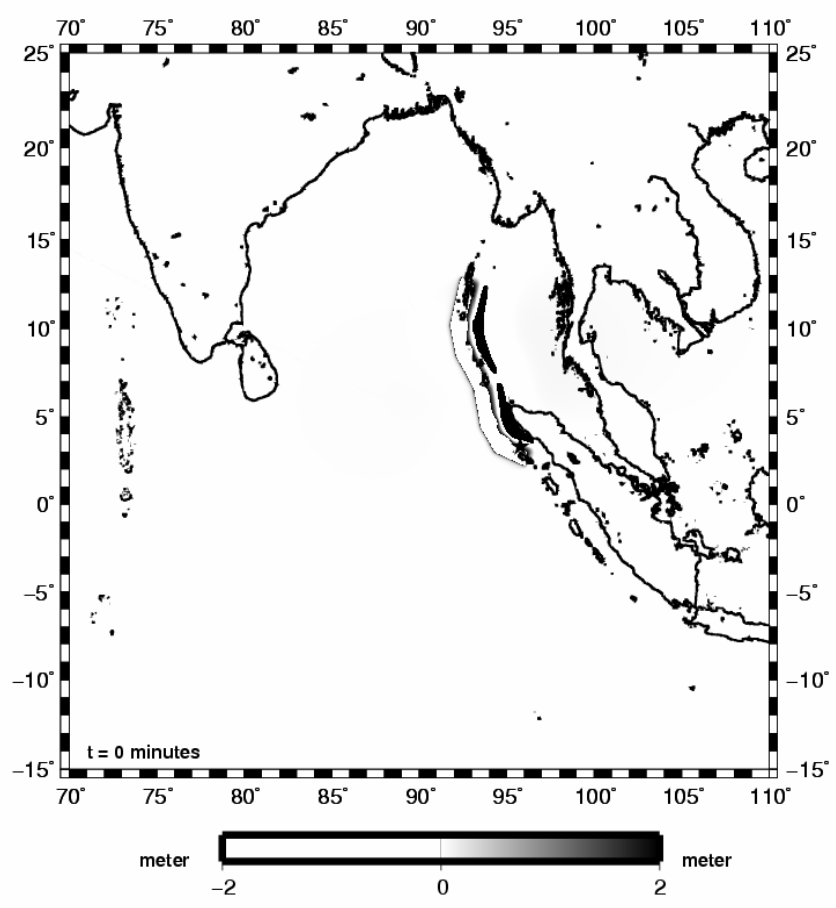

Figure 7 The Initial Model based on GFZ Potsdam model. The initial model was calculated based on the fault parameters given by GFZ Potsdam as listed in Table 1. The slip distribution was assumed homogenous for the entire fault and the dynamic effects of fault motion (rupture velocity and rising time) were assumed negligible.

The 2004 Aceh tsunami simulation was performed for a study area of $40^{\circ} \times 40^{\circ}$. The study area covers most of the northern part of the Indian Ocean region that ranges from $70^{\circ}$ to $110^{0}$ East and from $-15^{0}$ South to $25^{\circ}$ North. Fig. 6 shows the study area for tsunami simulation. The study area was divided into $1200 \mathrm{x}$ 1200 blocks with the size of each block is approximately $3700 \mathrm{~m} \times 3700 \mathrm{~m}(\Delta \mathrm{x}$ $=\Delta \mathrm{y}=2$ minutes) and $\Delta \mathrm{t}=1.5$ seconds. The bathymetry data was taken from 
the ETOPO2 (NOAA, 2005b). The numerical simulation was performed for 300 minutes.

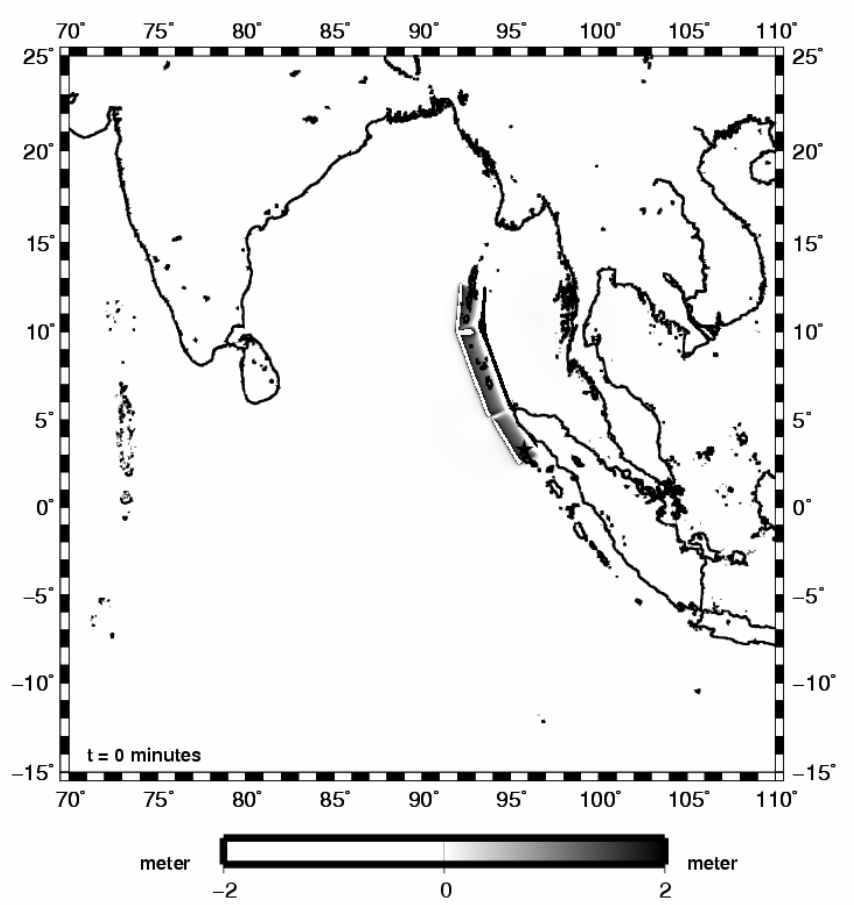

Figure 8 The Initial Model based on Tohoku University model. The initial model was calculated based on the fault parameters used by Tohoku University as listed in Table 1. The slip distribution was assumed homogenous for the entire fault and the dynamic effects of fault motion (rupture velocity and rising time) were assumed negligible.

In a numerical tsunami simulation the tsunami source usually is assumed as vertical deformation on the sea bottom caused by earthquake faulting. In this study the fault parameters proposed by GFZ Potsdam (2004) and Tohoku University (2004) listed in Table 1 were utilized to calculate the vertical deformation of the sea bottom. The calculation was done by applying a method that was developed by Mansinha and Symlie (1971). Basically the vertical deformation of the sea bottom was calculated as a function of fault parameters strike, dip, rake, length, width and slip. The slip distribution was assumed homogeneous for the entire fault. The dynamic effects of fault motion (rupture velocity and rising time) were assumed negligible in this study. The calculated vertical deformation of the sea bottom was used as an initial model in the tsunami simulation. Fig. 7 and Fig. 8 show the initial models that were 
calculated based on the fault parameters proposed by GFZ Potsdam (2004) and Tohoku University (2004), respectively.

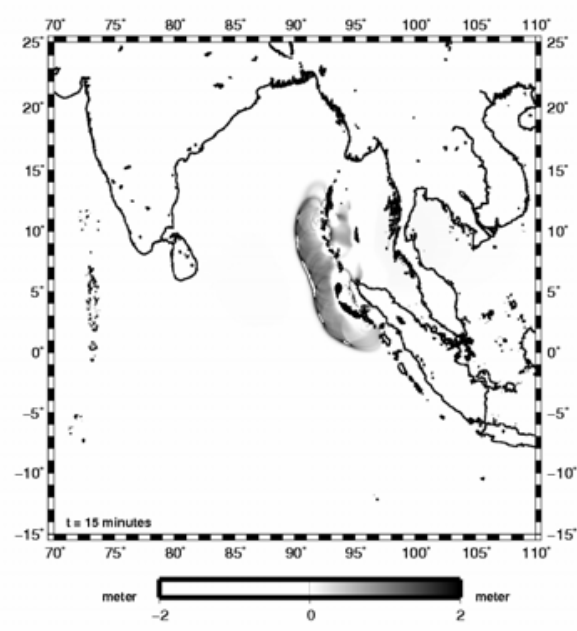

(a) Simulation at $\mathrm{t}=15$ minutes

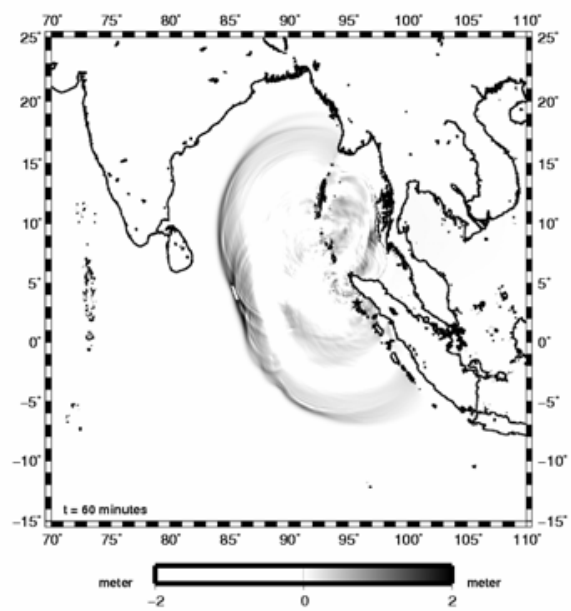

(c) Simulation at $\mathrm{t}=60$ minutes

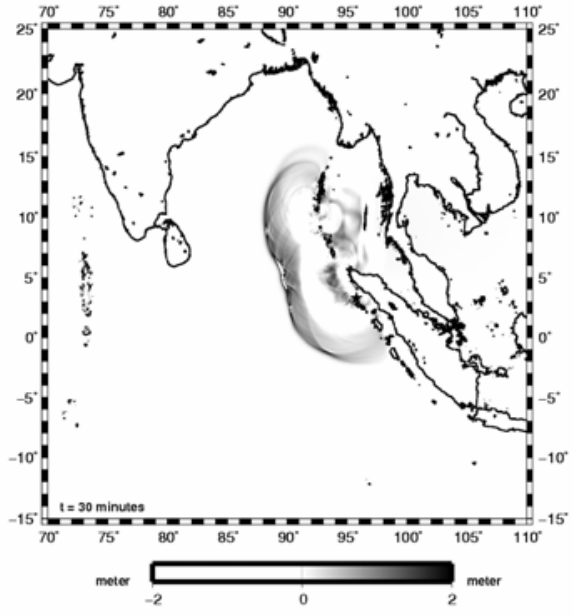

(b) Simulation at $\mathrm{t}=30$ minutes

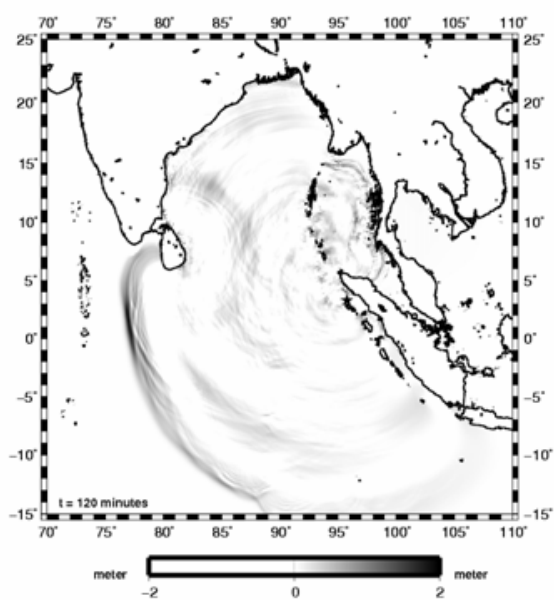

(d) Simulation at $\mathrm{t}=120$ minutes

Figure 9 Tsunami Simulation based on GFZ Potsdam model. The simulation was done based on the initial model shown in Fig. 7. The study area was divided into $1200 \times 1200$ blocks of $3700 \mathrm{~m} \times 3700 \mathrm{~m}$ in size and $\Delta t=1.5$ seconds. The simulation was performed for 300 minutes. Figs. 9 a, b, c and d show the estimated tsunami wave propagation at $\mathrm{t}=15,30,60$ and 120 minutes after the earthquake, respectively. 


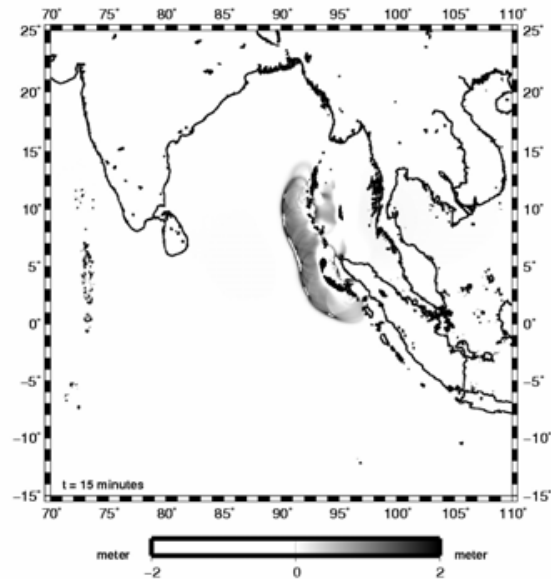

(a) Simulation at $\mathrm{t}=15$ minutes

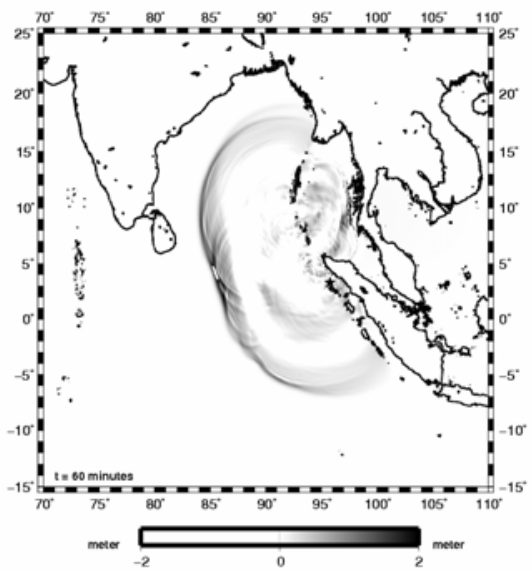

(c) Simulation at $\mathrm{t}=60$ minutes

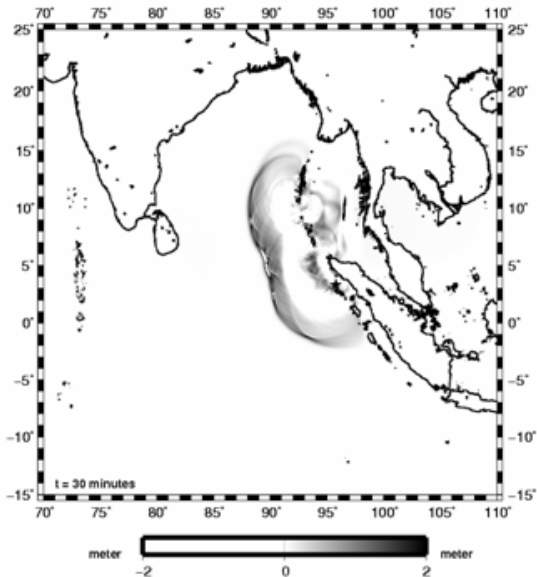

(b) Simulation at $\mathrm{t}=30$ minutes

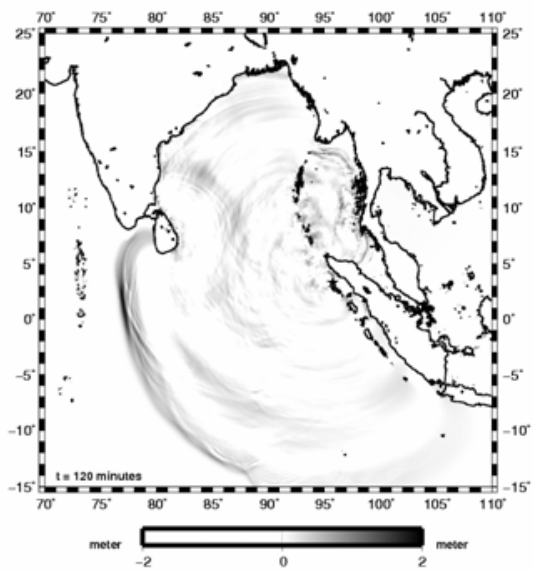

(d) Simulation at $\mathrm{t}=120$ minutes

Figure 10 Tsunami Simulation based on Tohoku University model. The simulation was done based on the initial model shown in Fig. 8. The study area was divided into $1200 \times 1200$ blocks of $3700 \mathrm{~m} \times 3700 \mathrm{~m}$ in size and $\Delta \mathrm{t}=1.5$ seconds. The simulation was performed for 300 minutes. Figs. 10 a, b, c and d show the estimated tsunami wave propagation at $t=15,30,60$ and 120 minutes after the earthquake, respectively.

Results of the tsunami simulation are presented by showing the estimated tsunami wave propagation at $\mathrm{t}=15,30,60$ and 120 minutes after the earthquake occurrence. Fig. 9 shows the tsunami simulation based on GFZ Potsdam model where figures $9 \mathrm{a}, 9 \mathrm{~b}, 9 \mathrm{c}$, and $9 \mathrm{~d}$ show the estimated tsunami wave propagation 
at $\mathrm{t}=15,30,60$ and 120 minutes after the earthquake, respectively. Fig. 10 shows the tsunami simulation based on Tohoku University model where figures $10 \mathrm{a}, 10 \mathrm{~b}, 10 \mathrm{c}$, and $10 \mathrm{~d}$ show the estimated tsunami wave propagation at $\mathrm{t}=15$, 30, 60 and 120 minutes after the earthquake, respectively. Fig. 9 and Fig. 10 show that the estimated tsunami wave propagation based on GFZ Potsdam and Tohoku University models have similar pattern.

It can be seen from Fig. 9a and Fig. 10a that at $\mathrm{t}=15$ minutes after the earthquake the peak of the calculated tsunami wave has reached the northernmost west coast of northern Sumatra, north coast of northern Sumatra and Nicobar Islands. Based on the simulation done in this study in general it can be estimated that the tsunami wave may reach west coast of northern Sumatra and north coast of northern Sumatra at about 15 to 25 minutes and 20 to 30 minutes after the earthquake, respectively. It can also be estimated that the tsunami wave may reach Nicobar Islands at about 5 to 10 minutes after the earthquake. Eyewitnesses reported that the tsunami wave reached west coast of northern Sumatra at about 15 to 30 minutes after the earthquake and north coast of northern Sumatra at about 20 to 30 minutes after the earthquake (DMC ITB, 2005). At $t=15$ minutes after the earthquake the tsunami wave has not yet reached the coastal areas along Malay Peninsula, Thailand, Myanmar, Bangladesh, India and Sri Lanka.

Fig. $9 b$ and $10 b$ show that at $t=30$ minutes after the earthquake the peak of the calculated tsunami wave has reached all of the west coast and north coast of northern Sumatra. The calculated tsunami wave has also reached the entire Nicobar and Andaman Islands. Based on the simulation in general it can be estimated that the tsunami wave may reach Andaman Islands at about 10 to 15 minutes after the earthquake. At $\mathrm{t}=30$ minutes after the earthquake the calculated tsunami wave has moved further westward and reached the middle part of Indian Ocean at longitude of about $90^{\circ}$ East. However, the tsunami wave has not yet reached the coastal areas along Malay Peninsula, Thailand, Myanmar, Bangladesh, India and Sri Lanka.

Fig. 9c and Fig. 10c show that at $t=60$ minutes after the earthquake the peak of the calculated tsunami wave has reached most of the west coast of Sumatra. At this time the tsunami wave has not yet reached the coastal areas along Malay Peninsula, Bangladesh, India and Sri Lanka. The calculated tsunami wave has moved further northward and reached the south coast of Myanmar. Based on the simulation in general it can be estimated that the tsunami wave may reach the south coast of Myanmar at about 60 to 70 minutes after the earthquake. The calculated tsunami wave has also moved further eastward and has been approaching the west coast of Thailand. Based on the simulation in general it can be estimated that the tsunami wave may reach the west coast of Thailand at 
about 90 to 100 minutes after the earthquake. Lay et al. (2005) reported that the tsunami wave reached Phuket in west coast of Thailand at about 111 minutes after the earthquake.

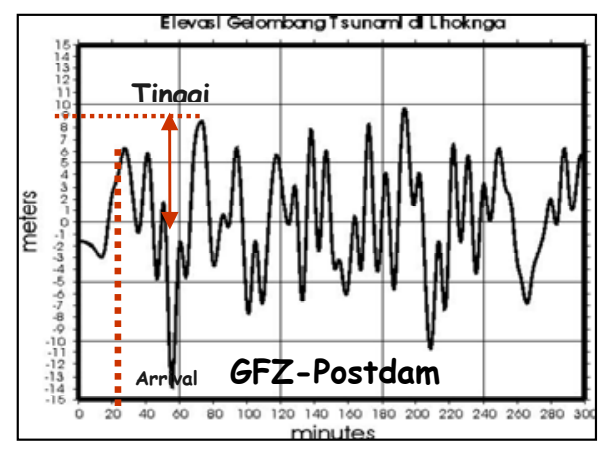

(a) Tsunami Elevation at Lhoknga (west coast of Aceh)

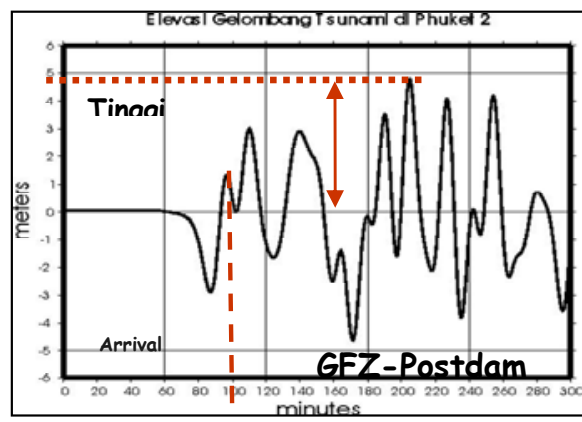

(c) Tsunami Elevation at Phuket, Thailand

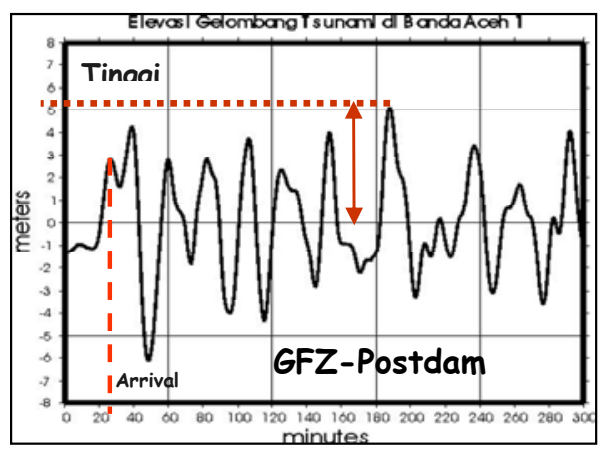

(b) Tsunami Elevation at Banda Aceh (north coast of Aceh)

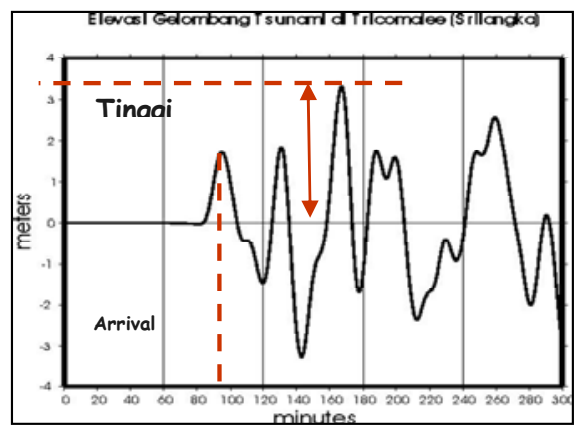

(d) Tsunami Elevation at Tricomalee, Sri Lanka

Figure 11 Tsunami Elevation based on GFZ Potsdam model. The calculated tsunami elevation based on GFZ Potsdam model at location numbers 1, 2, 3 and 4 shown in Fig. 6 are presented in the time series. Figs. 11 a, b, c and d show time series of the calculated tsunami elevation at Lhoknga, Banda Aceh, Phuket of Thailand and Tricomalee of Sri Lanka, respectively. The origin time $(t=0)$ is the time of earthquake occurrence and vertical axis 0 denotes the still water level.

Fig. $9 \mathrm{~d}$ and $10 \mathrm{~d}$ show that at $\mathrm{t}=120$ minutes after the earthquake the peak of the calculated tsunami wave has reached east coast of India and Sri Lanka, and most of the coast of Bengal Bay. The calculated tsunami wave has also reached the entire west coast of Thailand and south coast of Myanmar. At this time the tsunami wave has not yet reached coastal areas in the Malay Peninsula. Based 
on the simulation in general it can be estimated that the tsunami wave may reach the east coast of India and Sri Lanka at about 100 to 120 minutes after the earthquake. Lay et al. (2005) reported that the tsunami wave reached Vishakapatnam and Chennai in east coast of India at about 156 and 157 minutes after the earthquake, respectively.

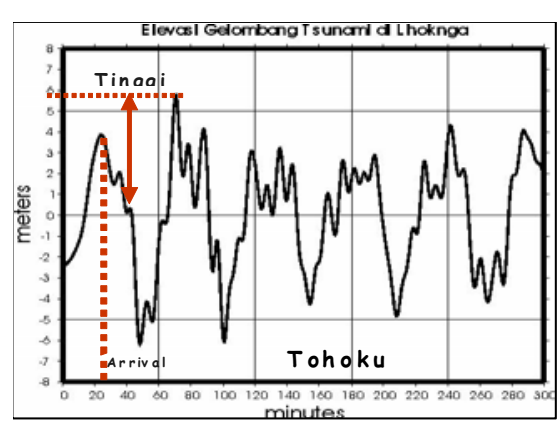

(a) Tsunami Elevation at Lhoknga (west coast of Aceh)

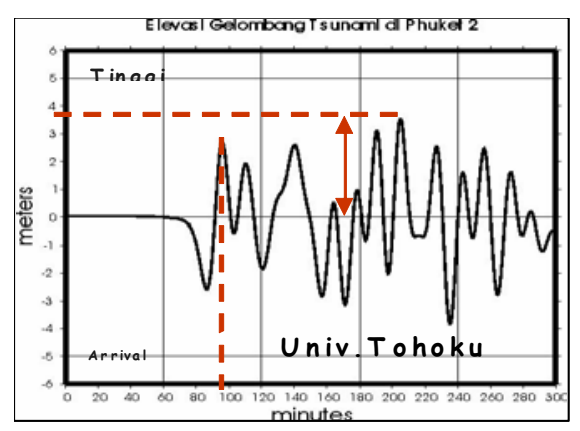

(c) Tsunami Elevation at Phuket, Thailand

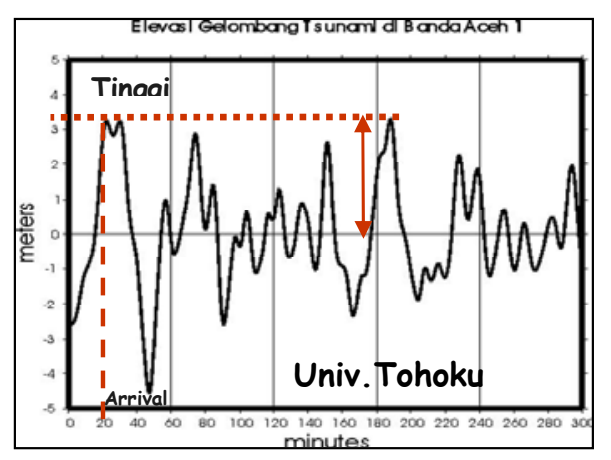

(b) Tsunami Elevation at Banda Aceh (north coast of Aceh)

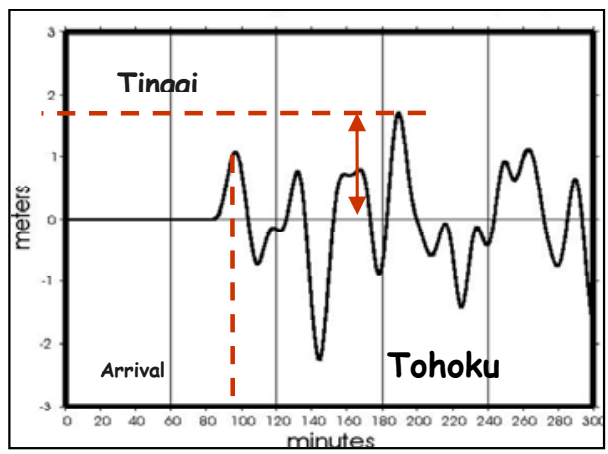

(d) Tsunami Elevation at Tricomalee, Sri Lanka

Figure 12 Tsunami Elevation based on Tohoku University model. The calculated tsunami elevation based on Tohoku University model at location numbers 1, 2, 3 and 4 shown in Fig. 6 are presented in the time series. Figs. 12 $\mathrm{a}, \mathrm{b}, \mathrm{c}$ and $\mathrm{d}$ show time series of the calculated tsunami elevation at Lhoknga, Banda Aceh, Phuket of Thailand and Tricomalee of Sri Lanka, respectively. The origin time $(\mathrm{t}=0)$ is the time of earthquake occurrence and vertical axis 0 denotes the still water level.

In order to analyze more detail the tsunami wave propagation, time series of the calculated tsunami elevation at several locations in the coast were presented. Time series of the calculated tsunami elevation were presented for Lhoknga in 
the west coast of Aceh, Banda Aceh in the north coast of Aceh, Phuket in the west of Thailand, and Tricomalee in the east coast of Sri Lanka. The four locations were shown as closed circles in Fig. 6 where Lhoknga and Banda Aceh were plotted as one circle since their location is very close. The time series of the calculated tsunami elevation based on GFZ Potsdam model is presented in Fig. 11, while the one that based on Tohoku University model is presented in Fig. 12.

Time series of the calculated tsunami elevation at Lhoknga in the west coast of Aceh (shown as circle number 1 in Fig. 6) were shown in Fig. 10a and Fig. 11a. The two time series have similar pattern. The two time series show that the peak of the calculated tsunami wave came several times to the location. The first peak of the calculated tsunami wave arrived at the location at about 20 minutes after the earthquake. Based on the calculated tsunami elevation in general it can be estimated that the first peak of tsunami wave may reach the west coast of Aceh at about 15 to 25 minutes after the earthquake. The maximum calculated tsunami height based on GFZ Potsdam model was about $10 \mathrm{~m}$, while the one based on Tohoku University model was about $6 \mathrm{~m}$.

At Banda Aceh in the north coast of Aceh (shown as circle number 2 in Fig. 6) the arrival times of the first peak of the calculated tsunami wave were about 25 minutes after the earthquake as shown in Fig. 11b and Fig. 12b. The two time series show similar pattern in which both have several peaks. Based on the calculated tsunami elevation in general it can be estimated that the first peak of tsunami wave may reach the north coast of Aceh at about 20 to 30 minutes after the earthquake. The maximum calculated tsunami height based on GFZ Potsdam model was about $3.5 \mathrm{~m}$, while the one based on Tohoku University model was about $5 \mathrm{~m}$.

Time series of the calculated tsunami elevation at Phuket in the west coast of Thailand (shown as circle number 3 in Fig. 6) were shown in Fig. 11c and Fig. 12c. The two time series show that the arrival times of the first peak of the calculated tsunami wave were about 95 minutes after the earthquake. Based on the calculated tsunami elevation in general it can be estimated that the first peak of tsunami wave may reach the west coast of Thailand at about 90 to 100 minutes after the earthquake. The maximum calculated tsunami height based on GFZ Potsdam model was about $5 \mathrm{~m}$, while the one based on Tohoku University model was about $4 \mathrm{~m}$.

At Tricomalee in the east coast of Sri Lanka (shown as circle number 4 in Fig. 6) the arrival times of the first peak of the calculated tsunami wave were about 100 minutes after the earthquake as shown in Fig. 10d and Fig. 11d. Based on the calculated tsunami elevation in general it can be estimated that the first peak 
of tsunami wave may reach the east coast of Sri Lanka and India at about 100 to 120 minutes after the earthquake. The maximum calculated tsunami height based on GFZ Potsdam model was about $3.5 \mathrm{~m}$, while the one based on Tohoku University model was about $1.5 \mathrm{~m}$.

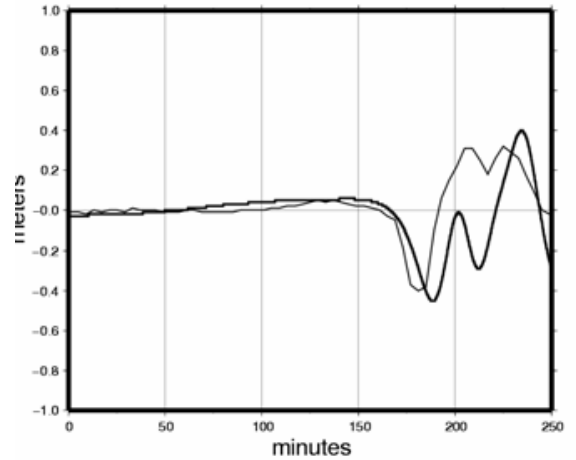

(a) Based on GFZ Potsdam model

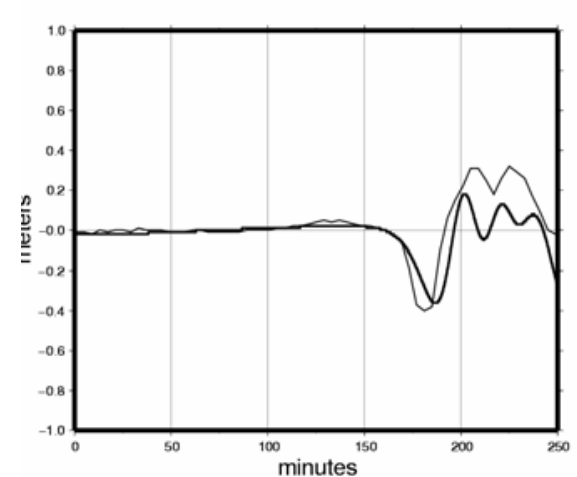

(a) Based on Tohoku University model

Figure 13 Observed and Calculated Tsunami Elevation at Belawan tide gauge station. Thin and thick lines depict the observed and calculated tsunami elevation, respectively. Fig. 13 a shows the calculated tsunami elevation based on GFZ Potsdam model and Fig. 13 b shows the calculated tsunami elevation based on Tohoku University model. The origin time $(\mathrm{t}=0)$ is 60 minutes after the earthquake and vertical axis 0 denotes the still water level.

In order to check the reliability of the tsunami simulation, the calculated tsunami elevation was compared with the observed tsunami elevation at Belawan tide gauge station that is located in the east coast of Sumatra. The Belawan tide gauge station located at latitude $3.78^{\circ}$ North and longitude $98.89^{\circ}$ East is shown as circle number 5 in Fig. 6. The comparison between the calculated tsunami elevation and the observed one at Belawan tide gauge station is shown in Fig. 13. The thin line shows the observed tsunami elevation while the bold line shows the calculated one. Fig. 13a shows comparison between the observed tsunami elevation and the calculated one based on GFZ Potsdam model, while Fig. 13b shows comparison between the observed tsunami elevation and the calculated one based on Tohoku University model. However, it should be noted that the calculated tsunami elevation was not calculated at the exact coordinate of the Belawan tide gauge station due to the limitation in size of block used in the numerical simulation. The calculated tsunami elevation at Belawan was calculated at latitude $3.80^{\circ}$ North and longitude $98.86^{\circ}$ East. 
The comparison between the calculated tsunami elevation/height and the observed one was analyzed based on their root mean square value and their coefficient correlation value. A root mean square error $\left(E_{R M S}\right)$ value was calculated by using the following equation

$$
E_{R M S}=\sqrt{\frac{1}{N} \sum_{i=1}^{N}\left(e l e v^{c a l}-e l e v^{o b s}\right)^{2}}
$$

where $N$ is number of data, elev ${ }^{\text {cal }}$ is the calculated tsunami height and elev $^{\text {obs }}$ is the observed tsunami height. The coefficient correlation value was calculated by using the following equation

$$
\begin{gathered}
r=\frac{\sum x y}{\sqrt{\sum x x \sum y y}} \\
\sum x y=\sum X Y-\left(\sum X \sum Y\right) / N ; \sum x x=\sum X^{2}-\left(\sum X^{2}\right) / N ; \sum y y= \\
\sum Y^{2}-\left(\sum Y^{2}\right) / N
\end{gathered}
$$

where $r$ is the coefficient correlation, $N$ is number of data, $X$ is the first data, and $Y$ is the second data. The coefficient correlation value ranges between -1 to +1 ; where $r=+1$ is perfect positive correlation, $r=-1$ is perfect negative correlation, and $r=0$ is no correlation.

The $E_{R M S}$ values based on GFZ Potsdam and Tohoku University models were $0.16 \mathrm{~m}$ and $0.10 \mathrm{~m}$, respectively. The coefficient correlation values $r$ based on GFZ Potsdam and Tohoku University models were 0.34 and 0.70 , respectively. Judging from the $E_{R M S}$ and coefficient correlation values it can be noted that the calculated tsunami heights and arrival times at the Belawan tide gauge station (Fig. 13), especially the one that was calculated based on Tohoku University model, show a relatively good agreement with the observed ones. The $E_{R M S}$ and coefficient correlation values also indicate that the simulation based on Tohoku University model seems to be more reliable than the one based on GFZ Potsdam model. However, comparison with more data from other tide gauge stations are needed to conclude that the simulation based on Tohoku University model is more reliable than the one based on GFZ Potsdam model.

Several weeks after the occurrence of tsunami the International Tsunami Survey Team led by Dr. Tsuji from the University of Tokyo conducted post tsunami survey in Aceh (Tsuji et al., 2005). Fig. 14 shows the maximum observed tsunami height reported by Tsuji et al. (2005). They reported that the maximum observed tsunami heights in the west coast of Aceh was about $34 \mathrm{~m}$, while in the north coast of Aceh was about $11 \mathrm{~m}$. 


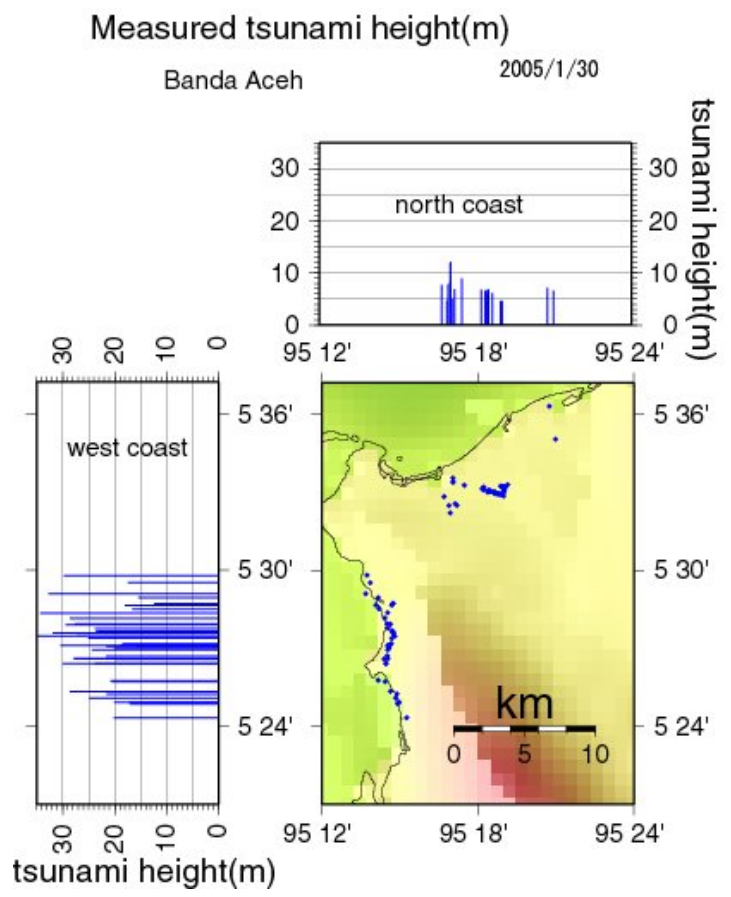

Figure 14 The Observed Tsunami Height. The maximum observed tsunami heights in the west coast of Aceh was about $34 \mathrm{~m}$, while in the north coast was about $11 \mathrm{~m}$. The data was taken from Tsuji et al. (2005).

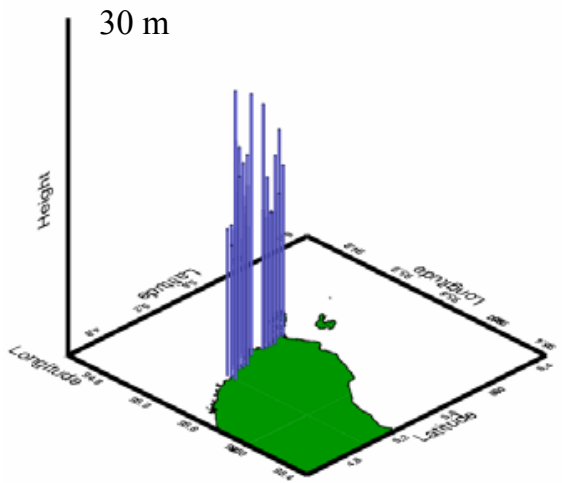

(a) Based on GFZ Postdam model

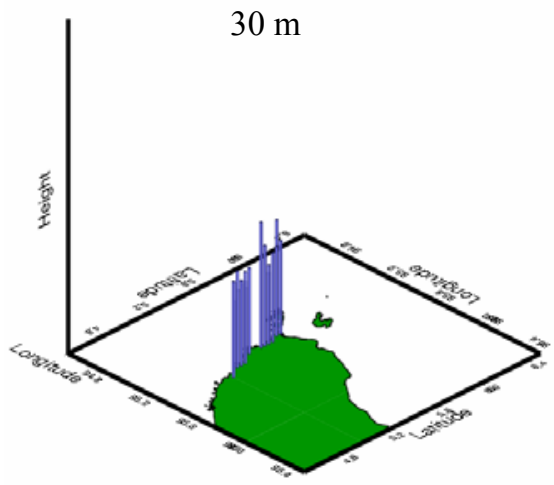

(b) Based on Tohoku University model

Figure 15 The Calculated Tsunami Heights in the west coast of Aceh. The maximum calculated tsunami heights in the west coast of Aceh was about $24 \mathrm{~m}$ based on GFZ Potsdam model (a) and was about $11 \mathrm{~m}$ based on Tohoku University model (b). 


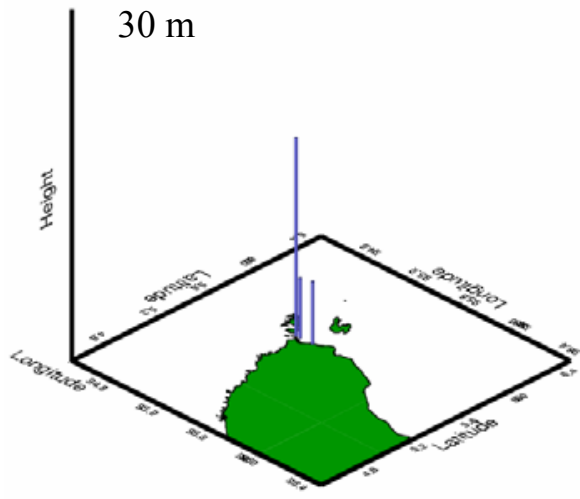

(a) Based on GFZ Postdam model

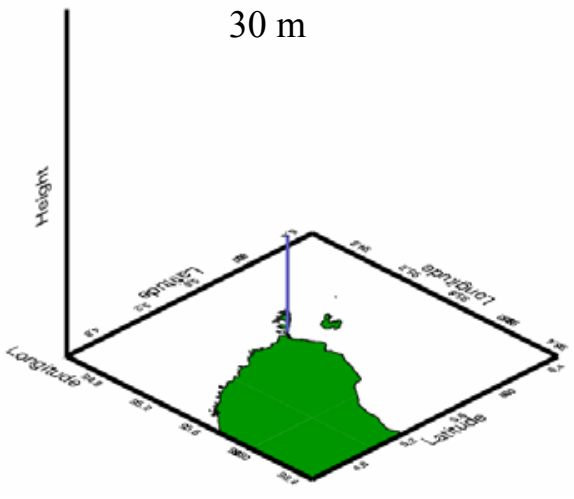

(b) Based on Tohoku University model

Figure 16 The Calculated Tsunami Heights in the north coast of Aceh. The maximum calculated tsunami heights in the north coast of Aceh was about $15 \mathrm{~m}$ based on GFZ Potsdam model (a) and was about $8 \mathrm{~m}$ based on Tohoku University model (b).

In order to make a comparison between the calculated tsunami heights and the observed ones reported by Tsuji et al. (2005), the maximum calculated tsunami heights were presented in Fig. 15 and Fig. 16. The maximum calculated tsunami heights at several locations in the west coast of Aceh are shown in Fig. 15, while Fig. 16 shows the calculated tsunami heights in the north coast of Aceh. In the west coast of Aceh the maximum calculated tsunami heights based on GFZ Potsdam and Tohoku University models were about $24 \mathrm{~m}$ (Fig. 15a) and $11 \mathrm{~m}$ (Fig. 15b), respectively. In the north coast of Aceh they were about 15 $\mathrm{m}$ (Fig. 16a) and $8 \mathrm{~m}$ (Fig. 16b), respectively. In general, except one data in the north coast of Aceh (Fig. 16a), the two calculated tsunami heights are smaller than the observed ones reported by Tsuji et al. (2005).

\section{$5 \quad$ Discussion}

The calculated arrival times at the coasts of northern Sumatra were relatively in good agreement with the observed ones reported by DMC ITB (2005). However, at the coasts of Thailand and India that are located far from the epicenter the calculated arrival times were earlier than the observed ones reported by Lay et al. (2005). Differences between the calculated arrival times and the observed or reported ones may be due to limitations in the tsunami simulation done in this study. First, the initial model was calculated based on the assumption that the dynamic effects of fault motion (rupture velocity and rising time) were negligible and the slip was assumed to occur at the same time 
along the fault. Several recent studies (Ammon et al., 2005; Bilham, 2005; Lay et al., 2005) suggested that the rupture propagated northward from the epicenter with average rupture velocity of about $2.5 \mathrm{~km} / \mathrm{s}$ and took about 10 minutes to reach the northern edge of rupture area. Therefore, by assuming that the slip occurred at the same time along the fault, the calculated arrival times especially in the northern area are earlier than the observed ones. By taking into account the dynamic effects of fault motion (Satake, 2004; Tanioka et. al, 2005) calculated arrival times show relatively good agreement with the observed ones reported by Lay et al. (2005). Second, the spatial grid $(\Delta x=\Delta y=3700 \mathrm{~m})$ used in this study was quite large. The large spatial grid used in the simulation tends to shorten the calculated travel times.

Generally it can be noted that the calculated tsunami heights in the west and north coast of Aceh were smaller than the observed ones reported by Tsuji et al. (2005). The differences between the calculated tsunami heights and the observed ones may be due to the limitations in the simulation. First, the bathymetry data used in the simulation were taken from a global bathymetry data set so that the size of blocks used in the simulation was quite large. As a comparison, Tanioka et. al (2005) utilized smaller spatial grid $1800 \mathrm{~m}$ in the deep sea and $600 \mathrm{~m}$ near the coast. By utilizing large spatial grid as in the case of this study, the local bathymetry effects that may tend to amplify the tsunami wave height might not be resolved in the simulation. This might cause that the calculated tsunami heights were smaller than the observed ones. Second, the slip distribution in this study was assumed homogeneous for the entire fault, i.e. $11 \mathrm{~m}$ based on Tohoku University model and $15 \mathrm{~m}$ based on GFZ Potsdam. However, several recent studies suggested that the slip distribution was heterogeneous (Ammon et al., 2005; Bilham, 2005; Ishii et al., 2005; Lay et al., 2005; Stein and Okal, 2005; Tanioka et al, 2005). The maximum slip in the southern part of rupture area was estimated about 20 to $22 \mathrm{~m}$ (Lay et al., 2005; Tanioka et al, 2005). The limitation in the assumed slip might cause the differences between the calculated tsunami heights and the observed or reported ones.

\section{Conclusions}

The conclusions of this study are following:

1. The tsunami simulation shows that the tsunami wave may reach NicobarAndaman Islands, west coast of northern Sumatra, north coast of northern Sumatra, south coast of Myanmar, west coast of Thailand, and the east coast of India and Sri Lanka at about 5 to 15,15 to 25,20 to 30, 60 to 70,90 to 100 , and 100 to 120 minutes after the earthquake, respectively. 
2. The maximum calculated tsunami heights at Lhoknga, Banda Aceh, Phuket of Thailand and Tricomalee of Sri Lanka were about 6 to $10 \mathrm{~m}, 3.5$ to $5 \mathrm{~m}$, 4 to $5 \mathrm{~m}$, and 1.5 to $3.5 \mathrm{~m}$, respectively. In general the calculated tsunami height based on GFZ Potsdam model was higher than the one based on Tohoku University model.

3. The calculated tsunami heights and arrival times show a relatively good agreement with the observed one at Belawan tide gauge station. The $\mathrm{E}_{\mathrm{RMS}}$ values based on GFZ Potsdam and Tohoku University models were $0.16 \mathrm{~m}$ and $0.10 \mathrm{~m}$, respectively. The coefficient correlation values based on GFZ Potsdam and Tohoku University models were 0.34 and 0.70 , respectively.

4. The maximum calculated tsunami heights in the west coast of Aceh were about 11 to $24 \mathrm{~m}$ and in the north coast of Aceh were about 8 to $15 \mathrm{~m}$.

\section{Acknowledgements}

We thank Dr. Sri Widiyantoro from Geophysics Research Group ITB and an anonymous referee who gave valuable comments on the improvement of this paper. This study is partly supported by a grant research of ITB, Riset Unggulan ITB tahun 2006.

\section{References}

1. Ammon, C.J., Ji, C., Thio, H.K., Robinson, D., Ni, S., Hjorleifsdottir, V., Kanamori, H., Lay, T., Das, S., Helberger, D., Ichinose, G., Polet, J. \& Wald, D., Rupture Process of the 2004 Sumatra-Andaman Earthquake. Science, Vol. 308, pp. 1133-1139 (2005).

2. Bilham, R., A Flying Start, Then a Slow Slip. Science, Vol. 308, pp. 1126-1127 (2005).

3. Department of Ocean Development (DOD), http://dod.nic.in/tsunami.pdf (2005).

4. Disaster Mitigation Center, Institute of Technology Bandung (DMC ITB), Report of the field survey of the 2004 Aceh earthquake and tsunami (Unpublished report written in Indonesian language) (2005).

5. Gusiakov, V.K., Historical Tsunami Database for the Pacific, 47 B.C 2000 A.D. Tsunami Laboratory, ICMMG SD RAS, Novosibirsk, Russia (CD-rom) (2002).

6. GFZ Potsdam, http://gfz-postdam.de/news/recent/archive/20041226/ TsunamiModeling/ModelDescription/content-en.html (2004).

7. Harvard University, http://seismology.harvard.edu/CMTsearch.html (2004).

8. IOC (Intergovernmental Oceanographic Commission), IUGG/IOC Time Project: Numerical Method of Tsunami Simulation with Leap-Frog Scheme, UNESCO (1997). 
9. Imamura, F. et al., Numerical Simulation of the 1992 Flores Tsunami: Interpretation of Tsunami Phenomena in Northeastern Flores Island and Damage at Babi Island, Topical Issue of Tsunami 1992-1994, Pure and Applied Geophysics, 144: no 3/4, 555-568 (1995).

10. Imamura, F., Review of Tsunami Simulation with a Finite Difference Method. In Long-Wave Run-up Models, edited by H. Yeh, P. Liu and C. Synolakis, World Scientific (1996).

11. Ishii, M., Shearer, P.M., Houston, H. \& Vidale, J.E., Extent, duration and speed of the 2004 Sumatra-Andaman earthquake imaged by the Hi-Net array, Nature, Vol. 435, pp. 933-936 (2005).

12. Latief, H., N.T. Puspito \& F. Imamura, Tsunami catalog and zones in Indonesia. Journal of Natural Disaster Science, Volume 22, Number 1, pp. 25-43 (2000).

13. Lay, T., Kanamori, H., Ammon, C.J., Nettles, M., Ward, S.N., Aster, R.C., Beck, S.L., Bilek, S.L., Brudzinski, M.R., Butler, R., DeShon, H.R., Ekstrom, G., Satake, K. \& Sipkin, S., The Great Sumatra-Andaman Earthquake of 26 December 2004, Science, Vol. 308, pp. 1127-1133 (2005).

14. Mansinha, L. \& D.E. Symlie, The Displacement Field of Inclined Faults. Bulletin of the Seismological Society of America, 61: no 45, 1433-1440 (1971).

15. Minster, J.B. \& T. Jordan, Present-day plate motions. Journal of Geophysical Research, Vol. 83, pp. 5331-5354 (1978).

16. Newcomb, K.R. \& W.R. McCann, Seismic history and seismotectonics of the Sunda arc. Journal of Geophysical Research, 92: 421-439 (1987).

17. NOAA, http://ngdc.noaa.gov/seg/hazard/tsu.html (2005a).

18. NOAA, http://ngdc.noaa.gov/mgg/global/global.html (2005b).

19. Puspito, N.T. \& K. Shimazaki, Mantle structure and seismotectonics of the Sunda and Banda arcs, Tectonophysics, 251: 215-228 (1995).

20. Puspito, N.T., Tsunami and Earthquake Activity in Indonesia, Proceedings of the International Workshop on Local Tsunami Warning and Mitigation, Petropavlovsk - Kamchatsky, Russia, September 2002, ISBN 5-8037-0110-6, pp. 138-145 (2002).

21. Stein, S. \& Okal, E.A., Speed and size of the Sumatra earthquake, Nature, Vol. 434, pp. 581-582 (2005).

22. Tanioka, Y., Yudhicara, T. Kususose, S. Kathiroli, Y. Nishimura, S. Iwasaki and K. Satake, 2005. Rupture process of the great 2004 SumatraAndaman earthquake estimated from tsunami waveforms. Earth and Planetary Science (in press).

23. Tohoku University, http://tsunami.civil.tohoku.ac.jp/hokusai2/topics/ 04sumatra/index.html (2004).

24. Tsuji, Y. et al., http://eri.u-tokyo.ac.jp/namegaya/surveylog/eindex.html (2005). 
25. USGS, http://earthquake.usgs.gov/eqinthenews/2004/usslav (2004a).

26. USGS, http://earthquake.usgs.gov/scitech/data global.html (2004b).

27. Yagi, Y., http://iisee.kenken.go.jp/staff/yagi/eq/sumatra2004/sumatra 2004.html (2004).

28. Yamanaka, Y., http://eri.u-tokyo.ac.jp/sanchu/Seismo Note/2004/ EIC161 ea.html (2004). 